\title{
From living wage to living hours - the Nordic version of the working poor
}

Ilsøe, Anna

Published in:

Labour \& Industry: A Journal of the Social and Economic Relations of Work

Publication date:

2016

Document version

Peer reviewed version

Citation for published version (APA):

Ilsøe, A. (2016). From living wage to living hours - the Nordic version of the working poor. Labour \& Industry: $A$ Journal of the Social and Economic Relations of Work, 26(1), 40-57.

http://dx.doi.org/10.1080/10301763.2016.1152534 


\title{
From living wage to living hours - the Nordic version of the working poor
}

\author{
Author: Anna Ilsøe, FAOS, \\ Department of Sociology, University of Copenhagen
}

\begin{abstract}
The development of service economies in the Western world has led to a debate on the quality of new service jobs as many are low-wage jobs with poor working conditions and career opportunities. Although the incidence of low-wage service work is somewhat lower in the Nordic countries than elsewhere in Europe, it is increasingly addressed and debated. Employees find it hard to make a living from their job and to work the working hours requested, whereas employers find it hard to attract and retain employees. This article introduces the concept of 'living hours' to capture the segmentation processes in low-wage service work in the private sector of Denmark, Norway and Sweden. The concept of living hours is used to explain developments in low wage service jobs that are not explained by the concept of a living wage. On the basis of cross-sectional data from the European Labour Force Survey, the article demonstrates how the increasing use of part-time and Sunday work since the crisis interacts with the increasing shares of young workers and migrant workers. The analysis focusses on retail and hotels/restaurants, which employ the majority of low-wage service workers in Denmark, Norway and Sweden.
\end{abstract}

Keywords: Nordic labour markets, low-wage workers, living hours 


\section{Introduction}

The development of service economies in the Western world has led to a debate on the quality of new service jobs as many are low-wage jobs with poor working conditions and career opportunities (Westergaard-Nielsen 2008; Gautié \& Schmitt 2009; Kalleberg 2011). Empirical and theoretical work has identified new segments of workers in private services at the very bottom of the labour market such as the 'emergent service workers' or the 'precariat' in the UK (Standing 2011; Savage, Devine, Cunningham et al. 2013) or the 'working poor' in the US (Klein \& Rones 1989). In these countries, unions have campaigned for a 'living wage' for the low-wage service workers (Luce 2007; Wills et al. 2009; Cambridge Policy Consultants 2014). A living wage is a country specific measure and can be defined as the hourly pay rate that a full time worker needs to earn to support a family of four at the poverty line (Anker 2006). It has been debated in literature how to measure the living wage, what its relation to the poverty line should be and whether one wage should support a family of four (ibid.). However, the main discussion within the living wage literature concentrates on how to regulate (statutory) minimum wages and raise them to levels that corresponds with actual living expenses (Luce 2007; Wills et al. 2009; Cambridge Policy Consultants 2014).

Low wage service work, which is characterized by wages significantly lower than the average wages on the labour market, has received relatively little research attention in the Nordic countries. Indeed, the incidence of low wage service work is somewhat lower in the Nordic countries than in the rest of Europe (Bosch \& Lehndorff 2005; Westergaard-Nielsen 2008). Furthermore, a comparatively high collective agreement coverage in the Nordic low-wage service sectors is argued to contribute to a higher wage level than is found among the same groups in, for instance, the UK and the US (Dølvik 2002; Andersen et al.2014). In recent 
years, low wage service work has been increasingly debated in the Nordic industrial relations literature (Tryggstad et al. 2011; Andersen \& Felbo-Kolding 2013; Neergaard 2012; Ilsøe \& Felbo-Kolding 2014). National surveys and case studies suggest that employees find it hard to work the hours requested in such jobs, whereas employers find it hard to attract and retain employees. However, only a few comparative analyses of the development in low wage service work in the Nordic countries have been conducted in the years following the global financial crisis (GFC).

This article introduces the concept of 'living hours' to help capture the segmentation processes in the Nordic low wage service sectors. The aim is to explain developments in low wage service jobs that are not explained by the concept of a living wage. 'Living hours' address two aspects of working hours that are of vital importance for workers - the length of the work week (i.e. if the number of paid hours per week that are needed to support a family) and the scheduling of the work week (i.e. the timing of working hours to allow working parents to take care of their children when the day care/school is closed). If these two conditions are not met, we find a lack of living hours, which makes it difficult for workers to raise a family. This can have severe consequences not only for the workers but also for the labour market as such. The lack of living wages have caused much debate in literature on how to regulate wages - a lack of living hours might raise important discussions on how to regulate working hours. The definition of the concept of living hours is based on a comparative empirical analysis of the recent developments in private low-wage service work in Denmark, Norway and Sweden after the GFC. 
Using annual data from the European Labour Force Survey, this article examines how working hours and worker profiles have changed in two low wage service sectors in the period from 2007 to 2013. We include the year 2007 to observe the impact of the crisis that hit the Nordic economies in 2008 to 2009 . The focus is on workers in retail and hotels/restaurants as the majority of low wage service workers in Denmark, Norway and Sweden work in these sectors (Bosch \& Lehndorff 2005; Westergaard-Nielsen 2008).

\section{Empirical and theoretical background}

The tertiarisation of Western economies has contributed to a diversification in pay and working conditions, including a growth in low wage work (Dølvik 2002; Bosch \& Lehndorff 2005). Low wage work in services has been studied intensely in Liberal Market Economies (LMEs) such as the UK and the US (Hall \& Soskice 2011). Indeed, in these two countries, it can be difficult to make a living even with a full-time, low wage job (Klein \& Rones 1989; Standing 2011; Savage et al. 2013).

Comparative studies of European labour markets document lower levels of low wage work in the Nordic countries than in the rest of Europe (Bosch \& Lehndorff 2005; Keune 2013). Wage levels are comparatively higher due to high collective agreement coverage (Andersen et al. 2014). Figures from 2007 demonstrate this difference; whereas the labour compensation per hour worked in the UK was GPB17 on average, the corresponding figures for retail and hotels/restaurants in the UK were GPB10 and GPB10, respectively (EU KLEMS 2011). In Denmark, the average figure was DKR217 (approximately GBP20) and the figures for retail and hotels/restaurants were DKR164 (approximately GBP15) and DKR136 (approximately GBP12) in 2007, respectively (ibid.). This means that the absolute wages in retail and 
hotels/restaurant were higher in Denmark than in the UK. Furthermore, wages in Danish retail and hotels/restaurants differed less from the average Danish wage than wages within the British retail and hotels/restaurant sectors when compared with the average British wage (ibid.). It should be mentioned that income and sales taxes as well as the costs of living are higher in Denmark than in the UK. These differences might call into question the comparative advantage for low wage workers in Denmark compared to the UK.

However, an isolated focus on wages may fail to highlight important developments in low wage service work in the Nordic countries. A growing body of literature on low wage service work in the Nordic countries indicates that features other than pay are under pressure and that the composition of workers is changing (Tryggstad et al. 2011; Nergaard 2012; Andersen \& Felbo-Kolding 2013; Mailand \& Larsen 2014;Ilsøe \& Felbo-Kolding 2014; Friberg et al. 2014). Empirical studies suggest that employees find it difficult to find full-time jobs or work the working time schedules requested in low wage service jobs (Tryggstad et al. 2011; Nergaard 2012; Mailand \& Larsen 2014). Concomitantly, employers find it hard to recruit and retain employees and increasingly employ, for instance, migrant workers and/or young workers (Andersen \& Felbo-Kolding 2013; Ilsøe \& Felbo-Kolding 2014; Friberg et al. 2014). This is particularly the case in sectors such as retail and hotels/restaurants where the traditional standard workers (white middle-aged males) seem to be an endangered species (ibid.).

In recent years, it has also been argued that a strong focus on low wage workers in LMEs such as the US and the UK is insufficient. Research suggests that dual labour markets also exist in Coordinated Market Economies (CMEs) such as Germany and France (Palier \& Thelen 2010; Bechter et al. 2012; Schulten \& Buschoff 2015). Drawing on Piore's (1971) theory of primary 
and secondary labour markets, King and Rueda (2008) demonstrate how low wage work exists in all industrialised economies. They distinguish between two forms of low wage work: standard cheap labour and non-standard cheap labour. Standard cheap labour involves low wage work on regular employment contracts (open-ended, full-time), whereas non-standard cheap labour covers low wage work on irregular employment contracts (temporary, part-time) (King \& Rueda, 2008). Based on empirical analyses of labour market developments from the mid-1970s until the turn of the millennium, King and Rueda (2008) argue that there is a tradeoff between standard and non-standard cheap labour, where employers in a given country either rely on the one or the other. Certain LMEs display high levels of standard cheap labour whilst CMEs like Denmark, Norway and Sweden show low shares of standard cheap labour (King \& Rudea 2008). However, Denmark, Norway and Sweden demonstrate similar or in some instances even higher incidences of non-standard cheap labour than the US and the UK (King \& Rueda 2008). Furthermore, King and Rueda (2008) argue that non-standard cheap labour often is performed by migrant workers.

Inspired by King and Rueda, we introduce the concept of 'living hours' here to capture the segmentation processes with regards to low-wage service workers in the Nordic countries. In line with their argument, we see a need to include features in addition to pay so as to understand the changing composition of workers in countries characterized by non-standard cheap labour. Recent empirical studies suggest that especially working hours are under pressure in the Nordic service industries (Tryggstad et al. 2011; Nergaard 2012; Mailand \& Larsen 2014). We define living hours with two aspects of working hours: 1. a sufficiently long work week, that is, the number of paid hours per week that are enough to support a family of four, and 2. a suitable scheduling of the work week, that is, working hours that allow working 
parents to care for their children when day care/school is closed. In other words, living hours are characterised by both the adequate length and scheduling of hours that allow workers to raise a family, an important precondition for staying in the same job for a longer period of time. This leads us to pose the two research questions:

1. Which developments in living hours (length and scheduling of hours) can be observed for low-wage service workers in the Nordic countries after the crisis? and

2. Which developments in worker profiles (young workers and migrant workers) can be observed in low-wage services in the Nordic countries for the same period?

\section{Methods and data}

Our empirical analysis focuses on two sectors within private services in Denmark, Norway and Sweden - retail and hotels/restaurants - and how living hours and worker profiles have changed within these sectors since the beginning of the last financial and economic crisis. Retail and hotels/restaurants employ the largest share of low-wage service workers in the private sector in all three countries (Bosch \& Lehndorff 2005). In Denmark, for instance, one in four workers in retail and hotels/restaurants earn less than two thirds of the median wage (Westergaard-Nielsen 2008). Denmark was hit relatively harder by the crisis in 2008 than Norway and Sweden, which make these three Nordic countries interesting cases for comparison (see next section). The Danish housing market was, among others, was very affected by the crisis, which contributed to an overall larger consequence for the Danish economy. We successfully applied for access to confidential micro-data from the European 
Labour Force Survey (LFS) and were granted access by Eurostat to cross-sectional annual data from 2007 to 2013 in the three countries.

The European LFS is a large household sample survey providing quarterly results on the labour participation of people aged 15 and over as well as on persons outside the labour force. LFS micro-data includes data for all EU member states in addition to Iceland, Norway and Switzerland. The Labour Force Surveys are conducted by national statistical institutes across Europe and are centrally processed by Eurostat. In Denmark, for instance, the LFS is conducted by Statistics Denmark under the name Arbejdskraftundersøgelsen (AKU). The advantage of LFS data is that it can be compared over time and across countries.

Few comparative analyses have been made regarding low wage service work in the Nordic countries after the crisis. Our immediate interest was therefore to perform descriptive analyses for the years 2007 to 2013 in Denmark, Norway and Sweden. Following our research questions, we focused on the development on two different forms of non-standard working hours:

a) part-time work, which reflects a deviation from the length of the standard work week (fulltime). This is inspired by King \& Rueda (2008) who note that this deviation is a key characteristic of non-standard cheap labour. This is an important aspect of living hours as fewer hours mean less pay which can make it difficult to cover basic living expenses. Although the hourly wage in low wage services might be higher in the Nordic countries than in LMEs like the UK, part-time work can undermine this advantage. Recent empirical studies suggest that part-time work forms a challenge to some workers in Nordic low wage services 
(Tryggstad et al. 2011; Nergaard 2012; Andersen \& Felbo-Kolding 2013). However, certain groups of workers, including students, might prefer part-time working (Marshall 2001; Booth \& van Ours 2008). An increase in part-time work in retail and hotels/restaurants can therefore attract new groups of workers, whereas the same development may cause other groups of workers to leave the sectors.

b) sunday work, which is a deviation from the standard scheduling of the work week (daytime, Monday through Friday). The inclusion of this indice was inspired by recent empirical studies of low wage service work in the Nordic countries which have addressed a number of challenges regarding the level of Sunday work (Tullberg et al. 2014; Ilsøe \& Felbo-Kolding 2014). Sunday work is especially relevant for employers in the private service sectors, where customers concentrate on weekends (Marginson \& Sisson 2004). Some workers are interested in Sunday work, too, as collectively-agreed wages usually are higher during weekends. However, working on Sundays (like working on Saturdays and in the evenings) can have negative effects on employees' work-life balance and employers' ability to attract employees with caregiving responsibilities (Presser 2005; Larsen 2005).

Furthermore, in line with our research questions, we focus on two different groups of nonstandard workers: c) Migrant workers (foreign born workers), a group highlighted by King \& Rueda (2008) and addressed by recent studies in Nordic low wage services (Andersen \& Felbo-Kolding 2013; Friberg et al. 2014), and d) young workers ( $<27$ years of age), which recent Swedish and Danish studies suggest form a large group in low wage services (Ilsøe \& Felbo-Kolding 2014; Tullberg et al. 2014). However, before entering the descriptive analysis 
of the LFS data for 2007 to 2013, we introduce recent developments within the Danish, Norwegian and Swedish labour market.

\section{Nordic labour markets - general trends}

The Swedish, Norwegian and Danish labour markets are mainly regulated by sector-level collective agreements negotiated between employers' organisations and trade unions. The public sector has full coverage by collective agreements in all three countries (100 percent), whereas 83 percent, 74 percent and 50 percent of workers within the private sector are covered by collective agreements in Sweden, Denmark and Norway respectively (Andersen et al. 2014: 33). Union densities are 80 percent or higher in their public sectors, and in the private sector, 69 percent of Danes, 65 percent of Swedes and 38 percent of Norwegians are trade union members (Andersen et al. 2014). However, the figures are somewhat lower than the average in retail (62, 57 and 25 percent) and hotels/restaurants (49, 41 and 24) (ibid.: 75).

If we compare recent developments in wages in the Nordic countries, we find less wage disparity than in other countries. As mentioned earlier, figures for labour compensation per hour worked demonstrate lower wage disparity in a CME like Denmark than in an LME like the UK (EU KLEMS 2011). However, the difference in wages between manufacturing on the one side and retail/hotels/restaurants on the other is also larger in a CME such as Germany than in Denmark, Norway and Sweden (Andersen et al. 2014). It has been argued that the strong coordination between social partners in the Nordic labour markets can explain why wage differences are less marked across sectors (ibid.). In recent years, they have had a strong focus on employment rates. In 2008, they were well above 80 percent in Denmark, Norway and Sweden (Andersen et al. 2014). However, financial and economic crisis meant that 
unemployment levels grew - especially in Denmark, somewhat in Sweden and less so in Norway. In 2012, the employment rate was about 80 percent in Norway and Sweden, whereas it dropped below 80 percent in Denmark (ibid.).

\section{Changes in working hours and worker profiles in Nordic low-wage services}

The descriptive analyses of LFS data from Denmark, Norway and Sweden demonstrated that the shares of part-time and Sunday work, along with the number of young people and migrant workers, were above average in hotels/restaurants in 2013 (see Table 1). In retail, the results were mixed. In 2013, the shares of part-time work, Sunday work (except Norway) and young workers were higher than the general average for all sectors, whereas the shares of migrant workers were lower. Our analyses showed that levels have changed during the period 2007 to 2013 in all three countries. However, these changes varied somewhat across countries and across retail and hotels/restaurants. We now examine these developments more closely.

Table 1: Working hours and worker profiles in retail and hotels/restaurants. Figures from Sweden, Norway and Denmark in 2013 (percent)

\begin{tabular}{|c|c|c|c|c|c|c|c|c|c|c|c|c|}
\hline & \multicolumn{3}{|c|}{ Part-time work } & \multicolumn{3}{|c|}{ Sunday work } & \multicolumn{3}{|c|}{ Young (<27) workers } & \multicolumn{3}{|c|}{$\begin{array}{l}\text { Migrant (foreign-born) } \\
\text { workers }\end{array}$} \\
\hline & $\begin{array}{l}\text { All } \\
\text { sect. }\end{array}$ & Retail & $\begin{array}{l}\text { Hotels/ } \\
\text { Rest. }\end{array}$ & $\begin{array}{l}\text { All } \\
\text { Sect. }\end{array}$ & Retail & $\begin{array}{l}\text { Hotels/ } \\
\text { Rest. }\end{array}$ & $\begin{array}{l}\text { All } \\
\text { sect. }\end{array}$ & Retail & $\begin{array}{l}\text { Hotels/ } \\
\text { Rest. }\end{array}$ & $\begin{array}{l}\text { All } \\
\text { sect. }\end{array}$ & Retail & $\begin{array}{l}\text { Hotels/ } \\
\text { Rest. }\end{array}$ \\
\hline Sweden & 27 & 32 & 48 & 30 & 34 & 63 & 20 & 28 & 49 & 13 & 11 & 29 \\
\hline Norway & 27 & 38 & 50 & 30 & 14 & 52 & 21 & 37 & 48 & 12 & 11 & 29 \\
\hline Denmark & 30 & 47 & 64 & 38 & 45 & 65 & 26 & 52 & 70 & 8 & 6 & 16 \\
\hline
\end{tabular}

Source: Eurostat micro data. Own calculations.

$\mathrm{N}$, hotels/restaurants: Denmark $(\mathrm{N}=2512)$, Sweden $(\mathrm{N}=5028)$, Norway $(\mathrm{N}=310)$

$N$, retail: Denmark $(N=9769)$, Sweden $(N=19050)$, Norway $(N=1756)$ 


\section{Change in working hours}

\section{Part-time work}

In 2007, the prevalence of part-time work in hotels/restaurants was 33 percent in Sweden, 48 percent in Denmark and 50 percent in Norway (see Figure 1). After the crisis, the share of part-time workers within hotels/restaurants increased in Denmark to 64 percent in 2013 (most of the change took place in 2008 to 2010) whereas in Norway the share of part-time workers remained relatively stable at 50 percent. In Sweden, part-time work increased to 48 percent (most of the change happened in 2007 to 2008). Today, the share of part-time workers in hotels/restaurants is well above the general average in all three countries (see Table 1).

In retail, the share of part-time workers was 27 percent in Sweden, 30 percent in Denmark and 39 percent in Norway in 2007 (see Figure 2). The incidence of part-time work in Sweden and Norway remained relatively stable up until 2013, whereas in Denmark, the number of parttime workers increased from 30 to 47 percent (most of the change taking place in 2008 to 2010). In 2013, retail was above average when it came to the share of part-time workers in the Nordic labour markets (see Table 1). 


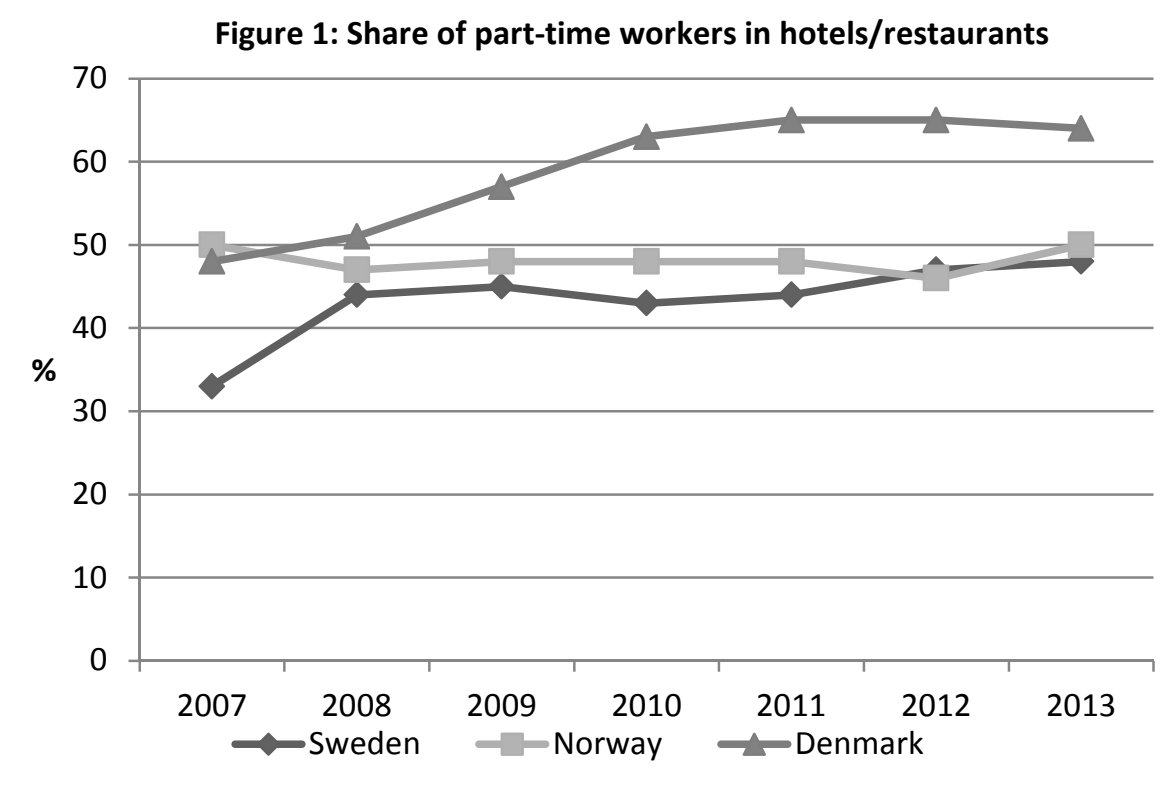

Source: Eurostat micro data. Own calculations.

Figure 2: Share of part-time workers in retail

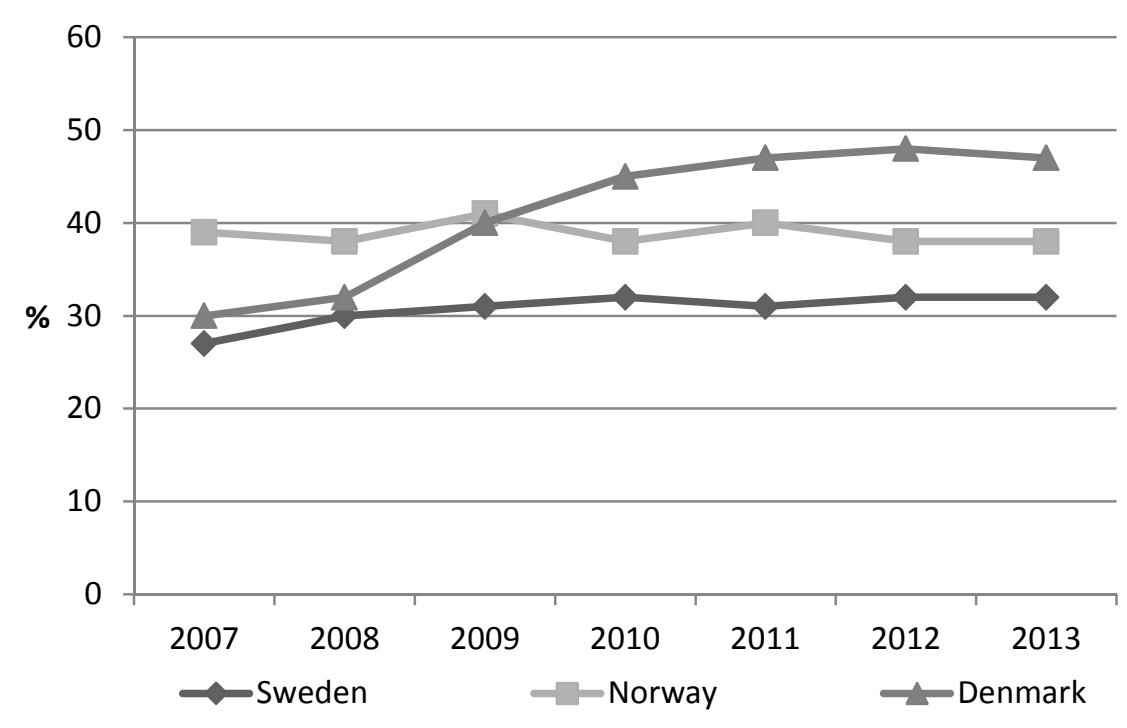

Source: Eurostat micro data. Own calculations.

King and Rueda (2008) demonstrated how Sweden, Denmark and Norway have higher or similar shares of non-standard cheap labour (including part-time) as LMEs. They base their findings on data from the mid-1970s to the turn of the millennium. Our analysis of data from 2007 to 2013 shows that part-time work continues to play a substantial role in low-wage 
service work in the Nordic countries. Furthermore, it seems that the share of part-time work has increased in Sweden and especially Denmark in the first years after the crisis (2008 to 2010). The share of part-time work in Norway remains stable, which can be explained by the fact that the Norwegian economy was less affected by the crisis than the Swedish and the Danish economy. It is possible that Danish and Swedish employers have used part-time contracts as a way to reduce expenses during the early crisis years. This could have been triggered by most workers being covered by collective agreements with relatively high minimum wages, and that employers could not reduce the hourly wage.

\section{Sunday work}

In 2007, more than half of the employees in hotels/restaurants worked on Sundays in Sweden, Norway and Denmark (see Figure 3). These levels of Sunday work changed slightly in the years after the crisis. In Denmark and Sweden, we can observe a slight increase in Sunday work to 65 and 63 percent, respectively, whilst in Norway, there has been a slight decrease in Sunday work to 52 percent. However, levels of Sunday work in hotels/restaurants are still well above average in all three countries.

The picture is very different if we turn our attention to recent developments in retail. In 2007, the share of Sunday work in retail was 23 percent in Denmark, 27 percent in Sweden and 14 percent in Norway (see Figure 4). These shares increased to 34 percent in Sweden and 45 percent in Denmark between 2007 and 2013, which means that the level of Sunday work is above average in Swedish and Danish retail today. The Norwegian level of Sunday work is still at 14 percent, which is lower than the average for all industries. The lower levels of Sunday work in Norway than Denmark and Sweden reflects Norway still having legislation in 
place that prohibits most shops to be open on Sundays (Lov om helligdager og helligdagsfred 1995 [Norwegian legislation on opening hours]). Similar legislation was removed over 30 years ago in Sweden and in 2012 in Denmark. However, the change in Danish legislation in 2012 does not seem to be the main driver of the recent development in Denmark, as the increase in Sunday work started earlier than 2012 (Lov om detailsalg fra butikker 2012 [Danish legislation on retail trade]).

Figure 3. Share of employees that usually or sometimes work on Sundays in

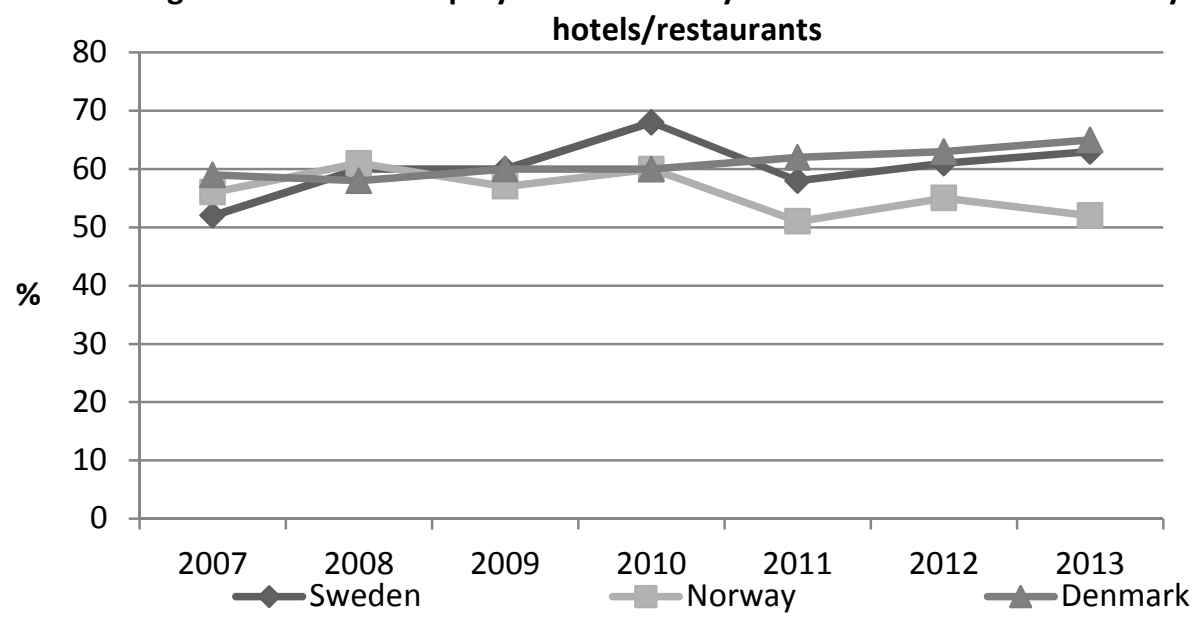

Source: Eurostat micro data. Own calculations.

Figure 4: Share of employees that usually or sometimes work on Sundays in retail

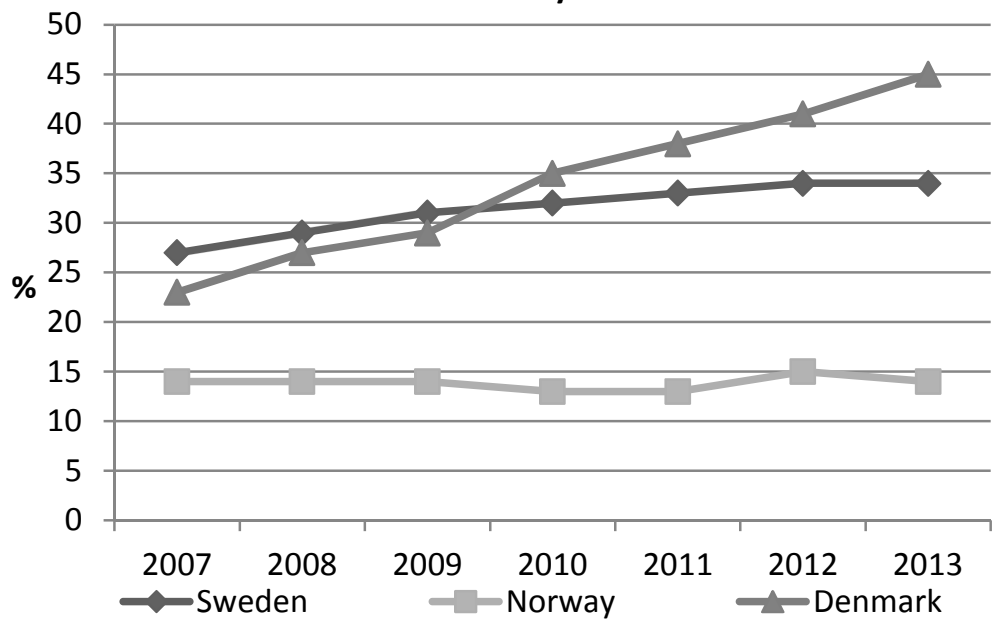

Source: Eurostat micro data. Own calculations. 


\section{Change in worker profiles}

\section{Young workers}

In 2007 , about 50 percent of workers in hotels/restaurants were young workers $(<27$ years of age) in Denmark, Sweden and Norway (see Figure 5). From 2007 to 2013, this share of young workers remained relatively unchanged in Sweden whilst it declined slightly in Norway. By contrast, during the same period, the Danish hotel/restaurant sector experienced a significant increase in the number of young people, with 70 percent of the workforce being under the age of 27 in 2013. However, in all three countries, the share of young workers in hotels/restaurants is above average when compared to the labour market in general (see Table 1).

If we turn our attention to retail, we find a similar pattern. In 2007, young workers constituted between 30 and 40 percent of the workforce in retail in the three countries (see Figure 6). Apart from a few alterations in Norway in 2008, these numbers have remained relatively stable in Sweden and Norway up until 2013, whereas the share of young people in Denmark grew to 52 percent in 2013. The increase in Denmark especially took place in the period 2008 to 2010 , when the country was hit hard by the financial crisis. Again, the shares of young workers in retail are above average compared to the Nordic labour markets in general (see Table 1) 
Figure 5: Share of young workers ( $<27$ years) in hotels/restaurants

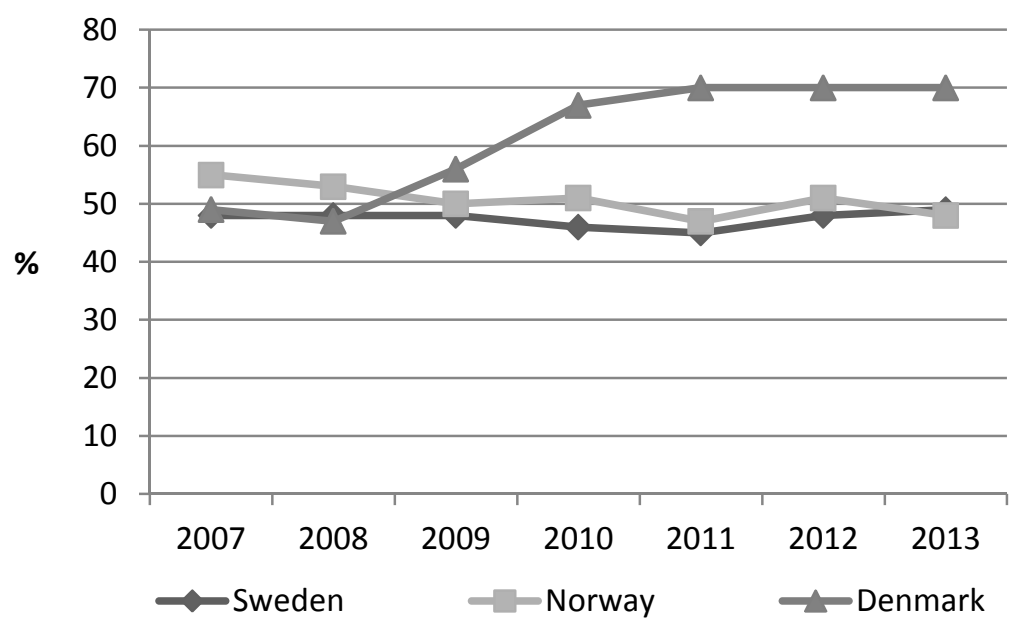

Source: Eurostat micro data. Own calculations.

Figure 6: Share of young workers ( $<27$ years) in retail

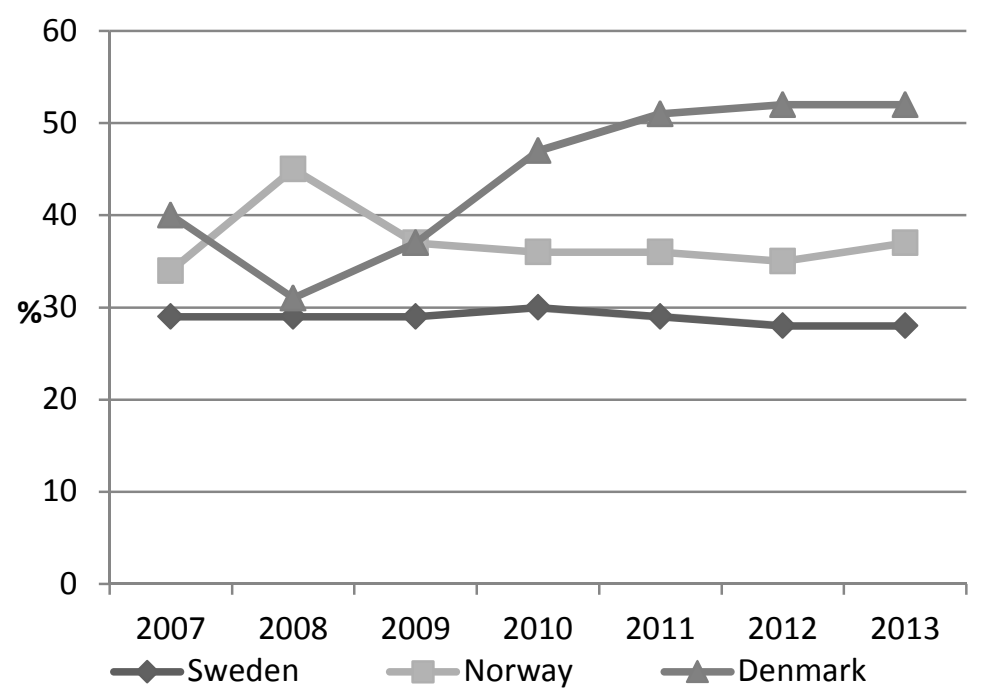

Source: Eurostat micro data. Own calculations. 


\section{Migrant workers}

In addition, the share of migrant workers changed after the crisis. In 2007, 17 percent of workers in hotels/restaurants in Denmark and Norway were migrant workers. In Sweden, this was the case for 27 percent of the workers in hotels/restaurants (see Figure 7). The share of migrant workers in hotels/restaurants is lower in Denmark, which can be related to much stricter legislation for migrant workers from outside the EU than in Norway and Sweden. Whilst the shares of migrant workers remained pretty stable in Denmark and Sweden in the years after the crisis, Norway witnessed an increase and reached the Swedish level with 29 percent in 2013. In sum, hotels/restaurants in all three countries employ more migrant workers than the average industry (see Table 1).

The share of migrant workers is generally lower in retail. In 2007, Norway and Denmark had seven percent migrant workers in retail, whereas Sweden had nine percent (see Figure 8). The share has increased in Sweden and Norway, as we find 11 percent migrant workers in 2013. In Denmark, the share has remained relatively unchanged - six percent of workers in retail were migrant workers in 2013. In all three countries, we find a lower share of migrant workers than is the average for all industries. One of the reasons why we find a lower share of foreign workers in retail could be due to language requirements; employers in retail value that employees who speak the national language because many job functions are related to sales and customer contact (Ilsøe \& Felbo-Kolding 2014). 
Figure 7: Share of migrant (foreign-born) workers in hotels/restaurants

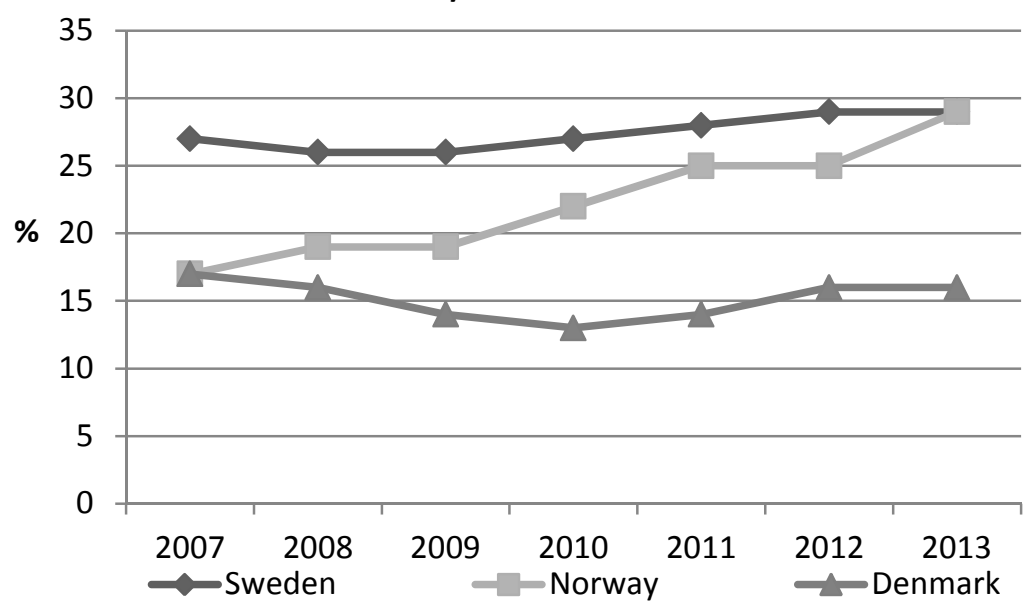

Source: Eurostat micro data. Own calculations.

Figure 8: Share of migrant (foreign-born) workers in retail

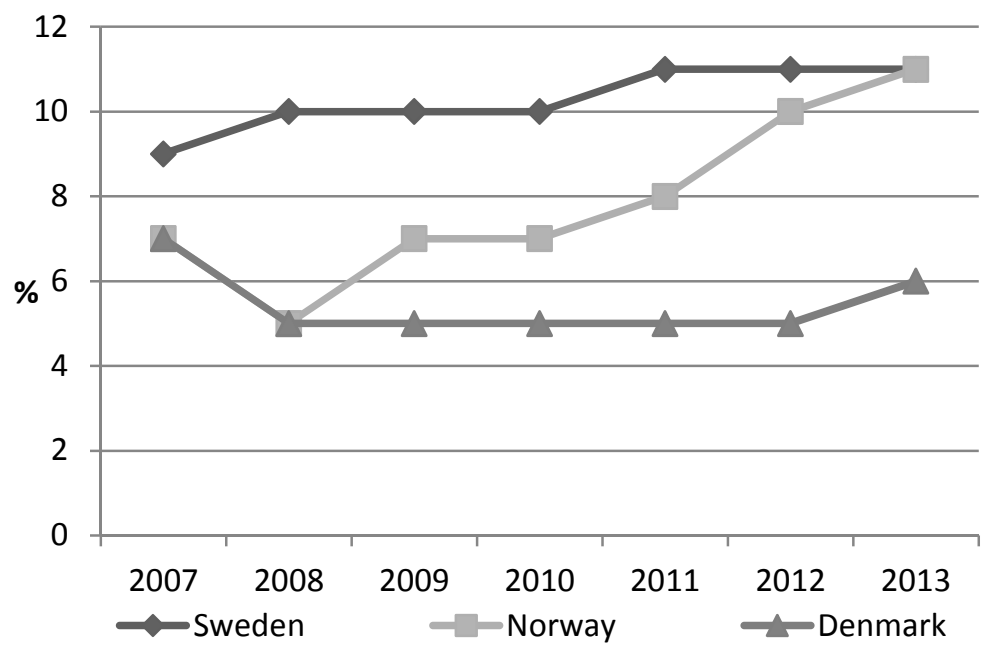

Source: Eurostat micro data. Own calculations.

\section{Relations between worker profiles and working hours}

A key question is whether the high levels of young workers and migrant workers in Nordic retail and hotels/restaurants are related to the high levels of part-time and Sunday work. If we take a closer look at the correspondence between worker profiles and working hours for each 
country, we find some interesting relationships. Many young workers and migrant workers (foreign-born) work on Sundays and part-time. For both groups, the two most frequent reasons for working part-time is participation in educational activities (that is, for instance, being a student) and that they were unable to find a full-time job. This is also true among women in both sectors, indicating that caring responsibilities are not a main driver for part-time work within the Nordic retail and hotels/restaurants sectors (see Table 2).

Table 2: Worker profiles vs. working hours in retail and hotels/restaurants. Figures from Sweden, Norway and Denmark in 2013 (percent)

\begin{tabular}{|c|c|c|c|c|c|c|c|c|}
\hline \multirow[t]{2}{*}{$\begin{array}{l}\text { Sweden } \\
2013(\%)\end{array}$} & \multicolumn{2}{|c|}{$\begin{array}{l}\text { Work } \\
\text { part-time }\end{array}$} & \multicolumn{2}{|c|}{$\begin{array}{l}{ }^{*} \text { Reason to part- } \\
\text { time: education }\end{array}$} & \multicolumn{2}{|c|}{$\begin{array}{l}\text { *Reason to part- } \\
\text { time: could not } \\
\text { find full-time job }\end{array}$} & \multicolumn{2}{|c|}{ Work on Sundays } \\
\hline & Retail & $\begin{array}{l}\text { Hotels } \\
\& \\
\text { Rest. }\end{array}$ & Retail & $\begin{array}{l}\text { Hotels } \\
\& \\
\text { Rest. }\end{array}$ & Retail & $\begin{array}{l}\text { Hotels } \\
\text { \& } \\
\text { Rest. }\end{array}$ & Retail & $\begin{array}{l}\text { Hotels } \\
\text { \& } \\
\text { Rest. }\end{array}$ \\
\hline Young $(<27)$ workers & 59 & 74 & 40 & 50 & 49 & 41 & 57 & 73 \\
\hline Migrant (foreign-born) workers & 27 & 37 & 11 & 24 & 47 & 52 & 36 & 60 \\
\hline Women & 51 & 57 & 14 & 33 & 38 & 41 & 44 & 63 \\
\hline \multirow[t]{2}{*}{$\begin{array}{l}\text { Norway } \\
2013(\%)\end{array}$} & \multicolumn{2}{|c|}{$\begin{array}{l}\text { Work } \\
\text { part-time }\end{array}$} & \multicolumn{2}{|c|}{$\begin{array}{l}{ }^{*} \text { Reason to part- } \\
\text { time: education }\end{array}$} & \multicolumn{2}{|c|}{$\begin{array}{l}\text { *Reason to part- } \\
\text { time: could not } \\
\text { find full-time job }\end{array}$} & \multicolumn{2}{|c|}{ Work on Sundays } \\
\hline & Retail & $\begin{array}{l}\text { Hotels } \\
\text { \& } \\
\text { Rest. }\end{array}$ & Retail & $\begin{array}{l}\text { Hotels } \\
\& \\
\text { Rest. }\end{array}$ & Retail & $\begin{array}{l}\text { Hotels } \\
\& \\
\text { Rest. }\end{array}$ & Retail & $\begin{array}{l}\text { Hotels } \\
\& \\
\text { Rest. }\end{array}$ \\
\hline Young (<27) workers & 75 & 73 & 83 & 87 & 11 & 9 & 19 & 64 \\
\hline Migrant (foreign-born) workers & 38 & 40 & 40 & 38 & 31 & 42 & 16 & 60 \\
\hline Women & 55 & 60 & 39 & 47 & 21 & 21 & 21 & 55 \\
\hline \multirow[t]{2}{*}{$\begin{array}{l}\text { Denmark } \\
2013(\%)\end{array}$} & \multicolumn{2}{|c|}{$\begin{array}{l}\text { Work } \\
\text { part-time }\end{array}$} & \multicolumn{2}{|c|}{$\begin{array}{l}{ }^{*} \text { Reason to part- } \\
\text { time: education }\end{array}$} & \multicolumn{2}{|c|}{$\begin{array}{l}\text { * Reason to part- } \\
\text { time: could not } \\
\text { find full-time job }\end{array}$} & \multicolumn{2}{|c|}{ Work on Sundays } \\
\hline & Retail & $\begin{array}{l}\text { Hotels } \\
\text { \& } \\
\text { Rest. }\end{array}$ & Retail & $\begin{array}{l}\text { Hotels } \\
\& \\
\text { Rest. }\end{array}$ & Retail & $\begin{array}{l}\text { Hotels } \\
\text { \& } \\
\text { Rest. }\end{array}$ & Retail & $\begin{array}{l}\text { Hotels } \\
\text { \& } \\
\text { Rest. }\end{array}$ \\
\hline Young (<27) workers & 81 & 84 & 90 & 87 & 5 & 7 & 60 & 68 \\
\hline Migrant (foreign-born) workers & 40 & 44 & 71 & 55 & 11 & 27 & 43 & 67 \\
\hline Women & 60 & 70 & 72 & 75 & 7 & 12 & 48 & 66 \\
\hline \multicolumn{9}{|c|}{ Source: Eurostat micro data. Own calculations. } \\
\hline \multicolumn{9}{|c|}{$\begin{array}{l}\text { *Question for part-time workers only - choice between five reasons: } 1 \text {. co } \\
\text { other family members, 3. Sickness, disability, } 4 \text {. Other personal or family re } \\
N \text {, hotels/restaurants: Denmark }(N=2512) \text {, Sweden }(N=5028) \text {, Norway }(N=3 \\
N \text {, retail: Denmark }(N=9769) \text {, Sweden }(N=19050) \text {, Norway }(N=1756)\end{array}$} \\
\hline
\end{tabular}


Young workers - the significance of educational activities

In Denmark, more than 80 percent of young workers in retail and hotels/restaurants work parttime, which is above the general average for both sectors. Nine out of 10 of these young workers combine part-time work with educational activities (see Table 2). We find a similar pattern in Norway, where three out of four young workers in retail and hotels/restaurants work part-time and more than 80 percent of these doing so because of educational activities. In Sweden, more than half of young workers in retail and hotels/restaurants work part-time and approximately half of these workers do so due to educational activities. However, the other half work part-time as they were unable to find a full-time job (ibid.). This is different to young part-time workers in Danish and Norwegian retail and hotels/restaurants. In general, however, there seems to be a significant group of young part-time workers in Nordic retail and hotels/restaurants who work part-time alongside their studies. Approximately two-thirds of young workers in Nordic retail and hotels/restaurants work on Sundays. The only exception from this pattern is the Norwegian retail sector where only two out of 10 young workers work on Sundays (see Table 2). The level of Sunday work among young workers in Swedish and Danish retail is above average for the sector (see Table 1 for comparison).

\section{Migrant workers - educational activities and lack of full-time jobs}

Migrant workers display a somewhat different working time pattern than young workers. Four out of 10 migrant workers in retail and hotels/restaurants in Denmark and Norway work parttime, whereas this is the case for three in 10 migrant workers in retail and hotels/restaurants in Sweden (see Table 2). This is less than the average for the sectors in all three countries (see Table 1). Migrant workers work part-time for various reasons. In Denmark, they often combine part-time work with educational activities, but a significant minority of migrant 
workers (between one and three out of 10) have also involuntarily ended up with part-time contracts as they were unable to find a full-time job. In Sweden, nearly one in two migrant workers work part-time because they could not find a full-time job, whereas a significant minority (between one and two out of 10) works part-time because of educational activities (ibid.). In Norway, migrant workers are split into two groups - four out of 10 work part-time due to education and about the same share work part-time because they could not find a fulltime job. The findings suggest that young people more often than migrant workers hold a parttime position in the Nordic retail and hotels/restaurant sectors. However, when migrant workers work on a part-time contract, they more often than young workers do so involuntarily. Six out of 10 migrant workers work on Sundays in hotels/restaurants, which is similar to young workers and the sectoral average (see Table 1 and 2 for comparison). In retail, four out of 10 migrant workers in Denmark and Sweden work on Sundays, whereas only two out of 10 do the same in Norway. This is below the average for the sector and less than the level of Sunday work for young workers (ibid).

\section{Conclusion and discussion}

A large body of literature has identified new segments of low wage workers in private services in LMEs like the UK and the US. This article introduces the concept of living hours to analyse emergent segments of low wage service workers in the Nordic countries. Living hours refer to two aspects of working hours - a sufficient length of the work week and a suitable scheduling of the work week - that allow workers to raise a family. Using annual data from the European LFS, we analysed the developments in working time and worker profiles in the period from 2007 to 2013 in Denmark, Norway and Sweden. The focus was on employees within retail and 
hotels/restaurants and on changes in the shares of part-time and Sunday work and of young workers and migrant workers.

Our analysis demonstrates a high share of part-time workers in Nordic retail and hotels/restaurants and that part-time work has become more widespread since the crisis. This is especially the case in Denmark which was hit harder by the crisis than Sweden and Norway. Furthermore, we find a high share of Sunday work in Nordic hotels/restaurants and in Swedish and Danish retail. There has been an increase in Sunday work within Swedish and Danish retail after the crisis. Indeed, the findings indirectly suggest that employers are not only increasingly using the length of the work week (part-time contracts) but also the scheduling of hours (Sunday work) to adjust to a changing economy. This means that both aspects of living hours - a sufficiently long work week and suitable scheduling of the work week - is being questioned in both sectors.

Living hours are defined as working hours that allow workers to raise a family and they are an important precondition for workers to stay in the same job for a longer period of time. A lack of living hours in certain sectors might lead to a preponderance of transitional workers. Our analysis shows an above average share of young workers in Nordic retail and hotels/restaurants. This is especially true in Denmark, where the share has increased since the crisis. In hotels/restaurants, the share of migrant workers is above average in all three countries and their numbers have increased in Sweden and Norway during the crisis years. Most young workers work part-time due to educational activities, whereas migrant workers are split in two groups on the question - they either work part-time because they could not find a full-time job or due to educational activities. Women mention the same main reasons to work 
part-time as young workers and migrants, indicating that part-time is not chosen to align with caregiving responsibilities. In sum, retail and hotels/restaurants in the Nordic countries employ large shares of workers that seem to work there temporarily (young students who need time to study) or involuntarily (migrant workers who are looking for a full-time job).

The concept of living hours captures developments in low wage service jobs that are not explained by the concept of a living wage. As mentioned earlier, living wages are measured as the hourly pay rate that a full-time worker needs to earn to support a family of four at the poverty line (Anker 2006). This definition potentially miss the effect of part-time contracts on wages and the effect of a family-unfriendly scheduling of hours on the ability to combine work with care-giving activities. We therefore suggest the introduction of living hours as a future field of research to uncover the segmentation mechanisms that relate to erosions in working time. This is especially relevant in the Nordic countries, where the hourly pay rates in low wage services are comparatively high, but at the same time, a preponderance of transitional workers is found.

Our findings also support an expansion of King and Rueda's (2008) definition of non-standard cheap labour to include not only a non-standard length of the work week but also a nonstandard scheduling of the work week. Furthermore, we suggest an exploration of how working hours in a broader sense can be integrated into King and Rueda's definition of nonstandard cheap labour and into studies of labour market segmentation in CMEs. Working hours seem to constitute an important part of the segmentation processes in countries with limited levels of standard cheap labour. Perhaps the scope, depth and dynamics of nonstandard cheap labour cannot be fully understood without analysis of the various forms of non- 
standard working hours including variations in the length (part-time work, marginal part-time work, zero-hour contracts), scheduling (Sunday work, Saturday work, evening work, shift work) and distribution (variable hours, flexitime) of hours.

\section{Implications}

The erosion of standard working hours and the overrepresentation of young and migrant workers in Nordic low-wage services have an array of consequences for workers, employers and overall models of labour market regulation. Migrant workers often involuntary end up in part-time jobs in Nordic retail and hotels/restaurants because they cannot find full-time employment. This means they earn less than full-time workers and may not be able to support a family. Accordingly, it can be argued that the growth in migrant workers in retail and hotels/restaurants - especially in Sweden and Norway - can be characterized as a Nordic version of the working poor. Contrary to this, young workers seem to deliberately choose parttime jobs in retail and hotels/restaurants because these jobs can be combined with their studies during their years of education. Hence, young workers in these sectors are expected to be quite satisfied with the working time arrangements.

The dominance of transitional workers in Nordic retail and hotels/restaurants can be a challenge for employers. Transaction costs are high, and relevant skills are not kept inside the company when employees are often replaced by newcomers. However, it might form an even larger challenge to the overall models of labour market regulation that transitional workers are concentrated in certain sectors. 
The regulation of pay and working conditions in the Nordic countries is based on organised labour and collective agreements (Andersen et al. 2014). The growth in migrant and young workers makes it more difficult for the sector-specific unions in Nordic retail and hotels/restaurants to organize workers and recruit new members, as transitional workers do not identify with the sectors. In Denmark, for instance, migrant workers and young workers often remain as non-union members or join alternative unions which are cheaper as they do not negotiate collective agreements (Ibsen et al. 2011). In general, there have been significant drops in union densities in Danish retail and hotels/restaurants over the last 10 years (Toubøl et al. 2015). Union densities are important for union bargaining power and the quality and coverage by collective agreements (Andersen et al. 2014). Further drops in union densities might therefore lead to less favourable levels of pay and working conditions. In Norway, certain legislation allows for the extension of collective agreements. However, research shows mixed results with regards to the effect of this form of regulation for wages in un-organised areas of the economy (Friberg et al. 2014). In contrast, the Norwegian law on opening hours seems to have been effective in preventing Sunday work in Norwegian retail. This type of legislation could be a relevant tool when preventing further erosion of working time for Nordic low-wage workers and perhaps further segmentation of the Nordic labour markets.

In general, it has been debated whether an increasing use of legislation would lead to improvements in the labour market regulation in the Nordic countries. The findings of studies on the effect of EU regulation - how it is implemented and how it affects pay and working conditions in the Nordic countries - are split on the subject. There is no doubt that legislation from the EU forms a challenge to the voluntarist tradition in the Nordic models of labour market regulation (Kristiansen 2015). However, specific EU directives implemented via 
collective agreements seem to have positively impacted on the pay and working conditions for low wage workers in the Nordic countries (Larsen \& Mailand 2014). Considering the relatively high coverage by collective agreements in the Nordic countries (Andersen et al. 2014), the changes in working time in Nordic retail and hotels/restaurants since 2007 are remarkable. Indeed, the findings suggest that the sector-level agreements in the Nordic private service sectors seem to be less efficient in securing a sufficient level of normal working hours (full-time jobs with a daytime schedule during weekdays) than minimum wage levels. Employers can use working time changes to handle challenges such as the financial and economic crisis. However, the changes introduced can result in permanently lower levels of living hours for Nordic low wage workers. Revisions of the current EU directives in terms of various aspects of working time (including the EU Working Time Directive and the EU Parttime Work Directive) might be a driver for implementing more effective safety nets that can secure minimum amounts of living hours in specific sectors. This would help prevent further development of a Nordic version of working poor involving migrant workers in hotels/restaurants and a further concentration of transitional workers in certain sectors involving young workers in retail. EU regulation forms a challenge to the Nordic voluntarist models of labour market regulation, but so does labour market segmentation that leads to an erosion of union density, pay and working conditions. 


\section{References}

Andersen, SK \& Felbo-Kolding, J (2013): Danske virksomheders brug af фsteuropaisk arbejdskraft. FAOS, Department of Sociology, University of Copenhagen.

Andersen, SK, Dølvik, JE \& Ibsen, CL (2014): De nordiske aftalemodeller i åbne markeder udfordringer og perspektiver. Oslo: Fafo.

Anker, R (2006): 'Living wages around the world: A new methodology and internationally comparable estimates'. International Labour Review, 145(4), 308-338.

Bechter, B, Brandl, B \& Meardi, G (2012): 'Sectors or countries? Typologies and levels of analysis in comparative industrial relations'. European Journal of Industrial Relations, 18 (3):185-202.

Booth, AL \& van Ours, JC (2008): 'Job Satisfaction and Family Happiness: The Part-Time Work Puzzle'. The Economic Journal, 118 (526): 77-99.

Bosch, G \& Lehndorff, S (eds.) (2005): Working in the Service Sector. A tale from different worlds. Oxon: Routledge.

Cambridge Policy Consultants (2014): Living Wage Special. Initiative Evaluation. Cambridge: Cambridge Policy Consultants. 
Dølvik, JE (ed.) (2002): At Your Service? Comparative Perspectives on Employment and Labour Relations in the European Private Sector Services. Brussels: P.I.E.-Peter Lang/European University Press.

EU KLEMS (2011): Growth and Productivity Accounts: November 2009 Release, updated March 2011. www.euklems.net.

Friberg, JH, Arnholtz, J, Eldring, L, Hansen, NW, Thorarins, F (2014): 'Nordic labour market institutions and new migrant workers: Polish migrants in Oslo, Copenhagen and Reykjavik'. European Journal of Industrial Relations 20 (1): 37-53.

Gautié, J \& Schmitt, J (eds.) (2011): Low-Wage Work in the Wealthy World. New York: Russell Sage Foundation.

Hall, PA \& Soskice, D (eds.) (2001): Varieties of Capitalism. The Institutional Foundations of Comparative Advantage. Oxford: Oxford University Press.

Ibsen, CL, Madsen, JS \& Due, J (2011): Hvem organiserer sig? Forklaringer på medlemskab affagforeninger og a-kasser. LO-DOKUMENTATION nr. 3. Copenhagen: LO.

Ilsøe, A \& Felbo-Kolding, J (2014): Samarbejde om arbejdstid og uddannelse - veje til rekruttering og fastholdelse i dansk detailhandel. Copenhagen: FAOS, Department of Sociology, University of Copenhagen. 
Kalleberg, AL (2011): Good Jobs, Bad Jobs: The Rise of Polarized and Precarious Employment Systems in the United States, 1970s to 2000s. New York: Russell Sage Foundation.

Keune, M (2013): 'Trade union responses to precarious work in seven European Countries'. International Journal of Labour Research, 5 (1): 59-78.

King, D \& Rueda, D (2008): “Cheap Labor: The New Politics of "Bread and Roses” in Industrial Democracies'. Perspectives on Politics, 6 (2): 279-297.

Klein, BW \& Rones, PL (1989): 'A Profile of The Working Poor'. Monthly Labor Review, 112: 3-13.

Kristiansen, J (2015): The growing conflict between European uniformity and national flexibility. Copenhagen: DJØF Publishing.

Larsen, TP (2005): 'Work and care strategies of European families: similarities or national differences?'. In Kröger, T \& Sipilä, J (eds): Overstreched - European Families up against the Needs of Work and Care. Oxford: Blackwell Publishing.

Larsen, TP, \& Mailand, M (2014): Bargaining for Social Rights in Sectors (BARSORIS): National Report Denmark. FAOS Forskningsnotat; No. 141. Copenhagen: Copenhagen University. 
Lov om detailsalg fra butikker 2012. [Danish legislation on retail trade]

Lov om helligdager og helligdagsfred 1995. [Norwegian legislation on opening hours]

Luce, S (2007): 'The US Living Wage Movement'. In Tuner, L \& Cornfield, DB (eds.): Labor in the New Urban Battlegrounds. Ithaca: Cornell University Press.

Marginson, P \& Sisson, K (2004): European Integration and Industrial Relations. Multi-Level Governance in the Making. Basingstoke: Palgrave Macmillan.

Marshall, K (2001): 'Part-time by choice'. Perspectives. Ottawa: Statistics Canada.

Nergaard, K (2012): Ufrivillig deltid, bemanningsstrategier og deltidsstillinger $i$ varehandel. Oslo: Fafo.

Palier, B \& Thelen, K (2010): 'Institutionalizing dualism: Complementarities and change in France and Germany'. Politics \& Society, 38 (1): 119-148.

Piore, M (1971): 'The dual labour market'. In Gordon, DM (ed): Problems in Political Economy: An Urban Perspective. Lexington: DC Heath.

Presser, HB (2006): 'Employment in a 24/7 economy: challenges for the family'. In Perrons, D, Fagan, C, McDowell, L, Ray, K \& Ward, K (eds): Gender Divisions and Working Time in the New Economy. Cheltenham: Edward Elgar. 
Savage, M, Devine, F, Cunningham, N, Taylor, M, Li, Y, Hjellbrekke, J, Le Roux, B, Friedman, S, Miles, A (2013): 'A New Model of Social Class? Findings from the BBC's Great British Class Survey Experiment'. Sociology, 47 (2): 219-250.

Schulten, T \& Buschoff, KS (2015): Sector-level Strategies against Precarious Employment in Germany. Düsseldorf: Hans Böckler Stiftung (WSI).

Standing, G, (2011): The Precariat: The New Dangerous Class. London: Bloomsbury Academic.

Toubøl, J, Ibsen, CL \& Larsen, AG (2015): Udviklingen i den faglige organisering på det segmenterede danske arbejdsmarked 1995-2012. FAOS report No 147. Copenhagen: Department of Sociology, University of Copenhagen.

Tryggstad, SC, Nergaard, K, Alsos, K, Berge, ØM, Bråten, M, Ødegård, AM (2011): Til renholdets pris. Oslo: Fafo.

Tullberg, M, Walter, L \& Blomquist, M (2014): Flexibel handel. Gothenburg: Gothenburg Research Institute.

Westergaard-Nielsen, N (ed) (2008): Low Wage Work in Denmark. New York: Russell Sage Foundation. 
Wills, J, Kakpo, N \& Begum, R (2009): The business case for the living wage:

The story of the cleaning service at Queen Mary, University of London. London: Queen Mary, University of London. 